\title{
Two medium-sized deinotheres (Proboscidea: Mammalia) from the Miocene rocks of the Eastern Carpathians Foreland (Romania)
}

\author{
Paul TुIBULEAC ${ }^{1, *}$ \\ 1 University "Alexandru loan Cuza" of laşi, Department of Geology, Bldv. Carol I, 20 A, 700506, Romania
}

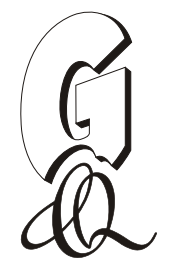

\begin{abstract}
Tibuleac, P., 2018. Two medium-sized deinotheres (Proboscidea: Mammalia) from the Miocene rocks of the Eastern Carpathians Foreland (Romania). Geological Quarterly, 62 (3): 669-684, doi: 10.7306/gq.1430

The paper summarizes the medium-sized deinothere records from Romania, improving the palaeontological data of two less-known specimens from the Eastern Carpathians Foreland. The area is famous primarily by the large deinothere of Găicena and Mânzaţi assigned to the "Deinotherium gigantissimum". Later, several fossils of Deinotherium were documented, but they remained generally unknown, and the morphological and biometrical data were not engaged in the further deinothere comparisons. The most important specimen is a fragmentary right hemimandible with well-fossilized $\mathrm{m} 1$ - $\mathrm{m} 2$, housed in the "Ion Borcea" Natural History Museum of Bacău. The p3-p4 and m3 preserved only the roots; even there are not obvious reworking signs. Furthermore, a tibia sin. fragment were firstly added. The fossil remains were unearthed from the Late Bessarabian rocks (MN 9) near Drăgessti (Bacău County). The second specimen represents an isolated M2 sin of Deinotherium giganteum stored at the Museum of Paleontology "Alexandru loan Cuza" University of laşi. It was collected from a microconglomerate bed (Early Bessarabian, ?MN 7-8-MN 9) cropping out in the Pietrăria Hill Quarry (Deleni, laşi County). The age of fossil-bearing layers was accurately documented by several mollusc assemblages.
\end{abstract}

Key words: hemimandible, molars, tibia, Drăgeşti, Deleni, Bessarabian.

\section{INTRODUCTION}

Deinotheres represent a browsing proboscidean family featured by several peculiarities of the cranial and mandibular skeleton (for detailed morphological characteristics see Lambert and Shoshani, 1998; Huttunen, 2002a). The first appearance datum of deinotheres is documented from Oligocene rocks ( 28-27 Ma) of Africa (Kappelman et al., 2003, Sanders et al., 2004) and their extinction is estimated before $1 \mathrm{Ma}$, also in Africa (Harris, 1979). During the evolution, the family showed a conservative general morphology on a continuous size-increase trend. Consequently, an informal classification divides the family into small- to large-sized species (e.g., Huttunen, 2002b).

The formal deinothere systematics is still a matter of debate; two main concepts being used in the literature. The first one consisting of two valid genera (Prodeinotherium and Deinotherium), was introduced by Éhik (1930) and resurrected by Harris $(1973,1975)$ and subsequent researchers (Gasparik, 1993, 2001; Göhlich, 1999; Huttunen, 2002a; Geraads et al., 2005; Duranthon et al., 2007; Vergiev and Markov, 2010; Aiglstorfer et al., 2014). The second one accepts as valid only the Deinotherium genus, being followed by Gräf (1957),

*E-mail: paul.tibuleac@uaic.ro

Received: January 15, 2018; accepted: April 26, 2018; first published online: September 28, 2018
Bachmayer and Zapfe (1976), Ginsburg and Chevrier (2001), Böhme et al. (2012), and Pickford and Pourabrishami (2013).

Herein, we follow the former concept. One also accepts four deinothere morphospecies/chronospecies: Prodeinotherium cuvieri (Kaup, 1832), P. bavaricum (von Meyer, 1833), Deinotherium giganteum, D. proavum (Eichwald, 1831) = D. gigantissimum Ştefănescu, 1891 - after Codrea (1994), even the fifth species - Deinotherium levius Jourdan, 1861 was recently resurrected (Böhme et al., 2012; Pickford and Pourabrishami, 2013).

\section{THE ROMANIAN DEINOTHERE SPECIMENS}

In Romania, the medium-sized deinotheres (Fig. 1) are less famous in comparison with the large specimens of Găicena and Mânzaţi (Maeotian, MN 11-12) assigned to the Deinotherium gigantissimum species by Ştefănescu $(1891,1895,1899$, 1905, 1910). Nearly a century later, Codrea (1994, and references herein) raised arguments to consider this species a junior synonym of $D$. proavum Eichwald 1835.

The first unambiguous deinothere specimen of Romania represents an upper molar of $D$. giganteum (Maeotian, MN 11-12) found at Găiceana (Ştefănescu, 1879, 1891), the data being improved later by several mandible fragments with three molars, fragments of symphysis and tusk, and two isolated premolars (Ştefănescu, 1895). New medium-sized deinothere fossils were added afterwards by Athanasiu (1907), who retrieved and described initially as " $D$. gigantissimum" several teeth from the Maeotian rocks of the Verneşti area (Argeş 


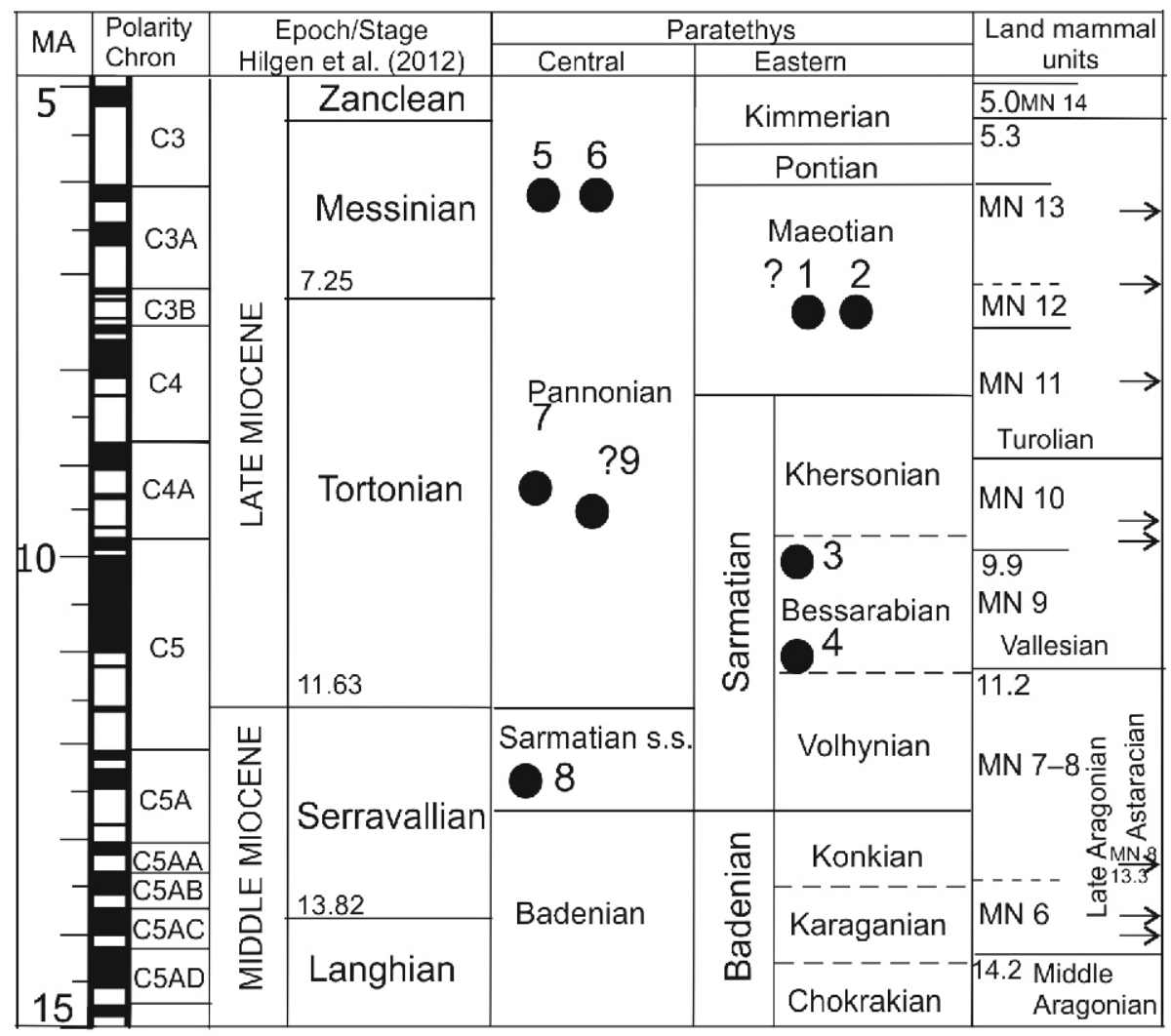

Fig. 1. Middle-sized deinothere specimens of Romania listed in the chronological review

1 - Găicena; 2 - Verneşti; 3 - Drăgeşti; 4 - Deleni; 5 - Becăştău Mine-Derna; 6 - BrusturiTătăruş; 7 - Supuru de Sus; 8 - Bârzaviţa II Quarry-Minişu de Sus; 9 - Vurpăr (see Romanian deinothere specimens). Middle-Late Miocene geochronology and chronostratigraphy after Hilgen et al. (2011); 3 and 4 are the specimens described in the paper

County). Later, Şova (1963) assigned a hemimandible fragment from Drăgeşti (Bacău County) to $D$. giganteum Kaup, 1829, after the general pattern of teeth and metrical comparison with several deinothere specimens. The occlusal morphology of $\mathrm{m} 1$ and $\mathrm{m} 2$ has not been described.

Macarovici and Zaharia (1968) described a left M2 of $D$. giganteum from the Early Bessarabian microconglomerates (?MN 7-8-MN 9) mined locally in the Pietrăria Hill Quarry (Deleni, laşi County). Fragments or even entire valves of Mactra pallasi Baily, 1858, Tapes sp., Cardium sp. and Cerithium sp., encountered within the microconglomerate clasts, documented an accurate stratigraphic age of the specimen.

In Transylvania, Jurcsák (1973) described a typical m3 dext. of $D$. giganteum found in the Becăştău Mine, Şimleul Silvaniei Basin (Derna, Bihor County), at the boundary between the marl and the bituminous layers (Late Pannonian-Early Pontian, according to Codrea et al., 2016). A distal fragment of a left hemimandible representing the downturned symphysis and a broken and degraded tusk was also recorded from the same basin at Brusturi-Tătăruş by Maxim (1947 - fide Jurcsák, 1973, 1982-1983). Later, Codrea (1989) reconstructed the main part of hemimandible after he recovered the proximal fragment of the same individual at the Museum of "Paleontology and Stratigraphy" of "Babeş-Bolyai" University, Cluj-Napoca. Finally, the specimen from Brusturi-Tătăruş includes the mandibular body with the tusk, with p3-m3 toothrow, of which only $\mathrm{m} 1$ and $\mathrm{m} 2$ are realtively well-preserved. The proximal ramus ascendens is missing. The Deinotherium giganteum remains of the Şimleul Silvaniei Basin are currently housed at the Museum of "Tării Crişului" Oradea and the Museum of "Paleontology and Stratigraphy", University of "Babeş-Bolyai", Cluj-Napoca, respectively.

Later, several isolated molars were reported from various Transylvanian areas. Firstly, Codrea and Andreica (1988) described a mesially damaged M2 dext. from the Pannonian sands of Supuru de Sus (Satu Mare County), which was also collected by Maxim. Then, Codrea et al. (1991) assigned a p4 dext. sampled from the Volhynian tuffaceous-diatomite deposits mined in the Bârzaviţa II Quarry-Minişu de Sus (Zarand Ba$\sin$, Arad County) to " $D$. levius". And the last specimen found so far was a p4 dext. of $D$. giganteum from Vurpăr (Sibiu County), housed at the "Brukenthal Natural Science" Museum in Sibiu (Codrea and Ciobanu, 2008). There are no accurate data on the level from which the tooth originated. The Pannonian age was assumed taking into account the regional geology. Both the p4s are missing the roots and are partly broken on the mesio-lingual side. Furthermore, several ambiguous specimens of Deinotherium sp., lacking biostratigraphic constraints, were also found (Codrea et al., 2016).

Herein, we present the specimens from Drăgeşti and Deleni (Eastern Carpathians Foreland), which were previously mentioned by Şova (1963) and Macarovici and Zaharia (1968), respectively. The mandible from Drăgeşti was not practically described. The assignment was based on the tooth pattern and dimensions. The Deleni molar was generally described (we added only a few details), but it was not compared. Both the specimens were derived from the layers with an accurate biostratigraphy documented by mollusc assemblages, and both are not known outside Romania. 


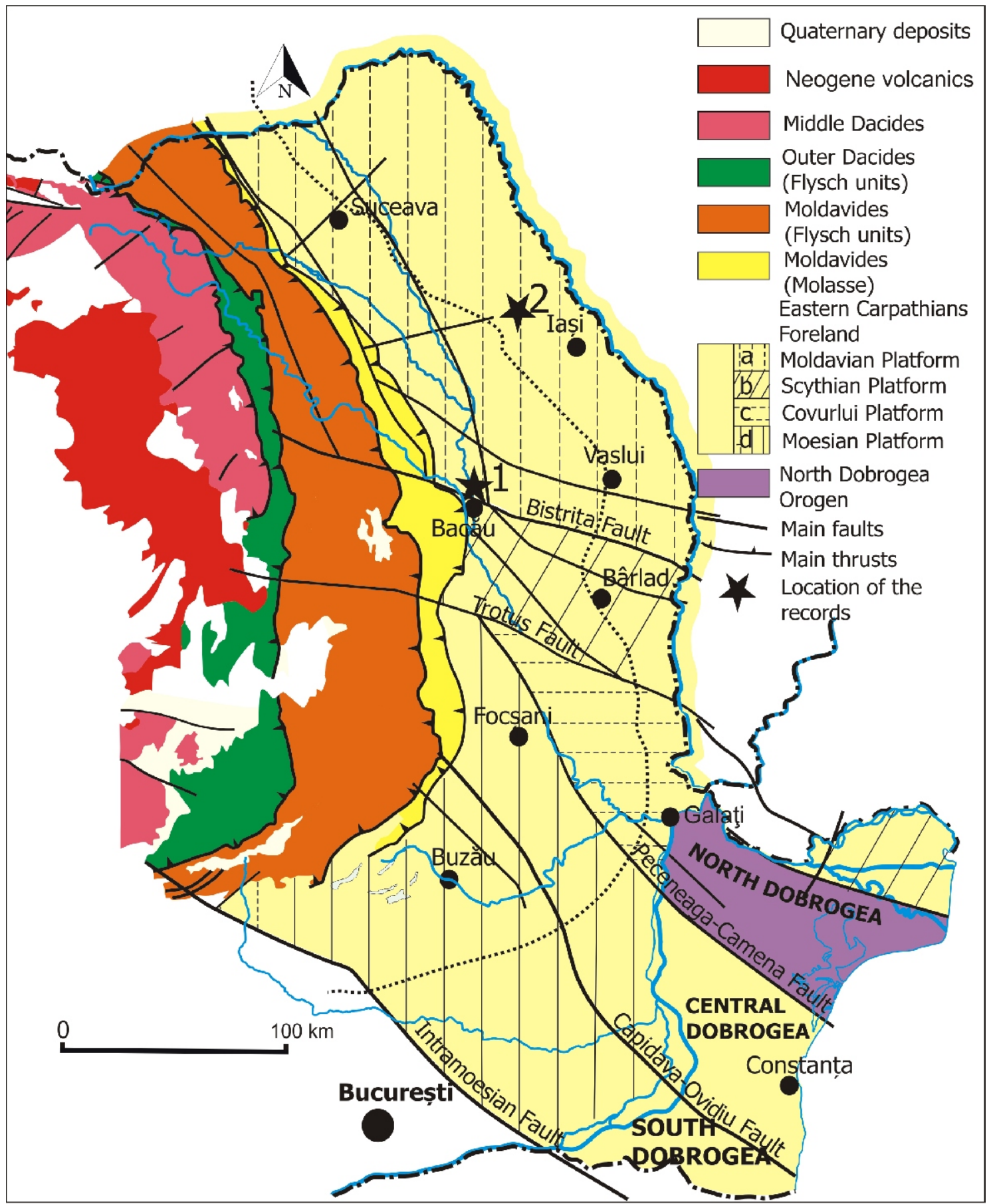

Fig. 2. Eastern Carpathians Foreland (Romania)

Compilation after Geological Map of Romania 1:1,000,000 (IGR) and Visarion et al. (1990), Răileanu et al. (2012); 1 - Drăgeşti (Bacău County); 2 - Deleni (laşi County)

\section{GEOLOGICAL FRAMEWORK}

The Eastern Carpathians Foreland (ECF) and South Carpathians Foreland (SCF) make up the foreland basin of the Romanian Carpathians, which is delimited by the mountain belt along the Pericarpathian Fault (Tărăpoancă, 2004, and references therein). The different lithospheric blocks and several particularities of the orogen-basin system evolution distinguish these two sectors.

The ECF covers the pre-Alpine Moldavian/East European and Scythian platforms, the Alpine Covurlui Platform (sensu
Ionesi, 1994), and the sector of the Moesian Platform located north-east of the Intramoesian Fault, named the Dobrogean sector or East Moesia (e.g., Paraschiv, 1979; Săndulescu, 1984; Săndulescu and Visarion, 1988; Visarion et al., 1988, 1990). Towards north and east, the ECF continues in the Republic of Moldova and Ukraine through the first three platforms (Fig. 2). The above-mentioned platforms are bounded by several trans-crustal fault systems showing primarily the main differences on the basement, and subsequently on the pre-Neogene successions. During the Neogene, the platforms evolved almost similarly into a classic foreland basin. 


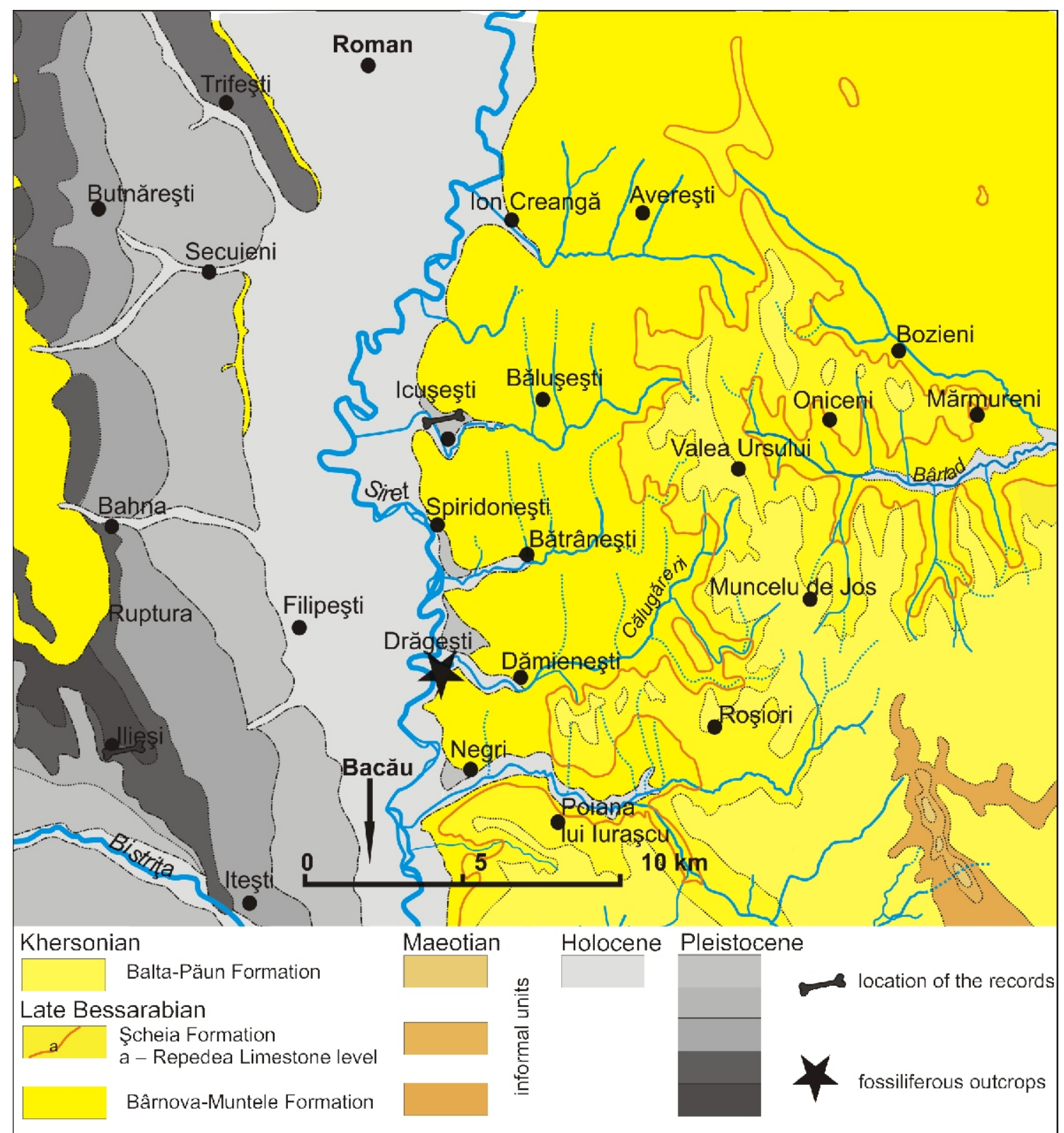

Fig. 3. Location of the Drăgeşti deinothere specimen: geological sketch along the Sireth River between Roman (north) and Bacău (south)

Compilation after Jeanrenaud (1967) and Folio 1:200,000 Bacău; the formations are named after lonesi et al. (2005)

\section{GEOLOGICAL FRAMEWORK OF THE SPECIMEN} FROM DRĂGEŞTI (BACĂU COUNTY)

The main deinothere remains were recorded from the marl and fine sand beds cropping out on the left bank of the Siret River, near the village of Drăgeşti (Bacău County), Moldavian Platform (Fig. 2). The Miocene sedimentary rocks of the area broadly complies the coeval succession of the inner part of the Moldavian Platform. Accordingly, a deltaic depositional environment was documented in the northwestern outcrops, and a brackish one towards the south-east, following the general retreat of the Paratethys Sea in the ECF (e.g., Jeanrenaud, 1967, 1971).

The Miocene outcrops are dependent on the north-south watershed (Avereşti surroundings, Valea Ursului, Muncelu de Jos, Roşiori and Poiana lui luraşcu villages) that separates the tributaries of the Siret River basin towards the west from those of the Bârlad River basin towards the east (Fig. 3).
Along the Siret basin, between lon Creangă (north), Icuşeşti and Negri localities, and further to the south (Fig. 3), Jeanrenaud (1967) mapped "clays" with sand levels ( 200 m thick) assigned to the "lower horizons of Bessarabian". Within this succession, the so-called "freshwater intercalations" cropping out at Golani (Avereştii de Jos) and Brad villages, with "Congeria moldavica Andrusov, 1897, Melanopsis sinzowi Brusina, 1885, Hydrobia ventrosa (Montagu, 1803), and $H$. elongata (Faujas in Eichwald, 1853)", represent the common lithological mark with the adjacent eastern part of the Moldavian Platform. The mark-level of Repedea oolitic limestone (here included in the Şcheia Formation) overlies comformably these deposits (approximately at $400 \mathrm{~m}$ elevation), outlining the above-mentioned watershed (Fig. 3). The sand and marls of the Balta-Păun Formation and the Maeotian rocks complete the Miocene succession in this area. 


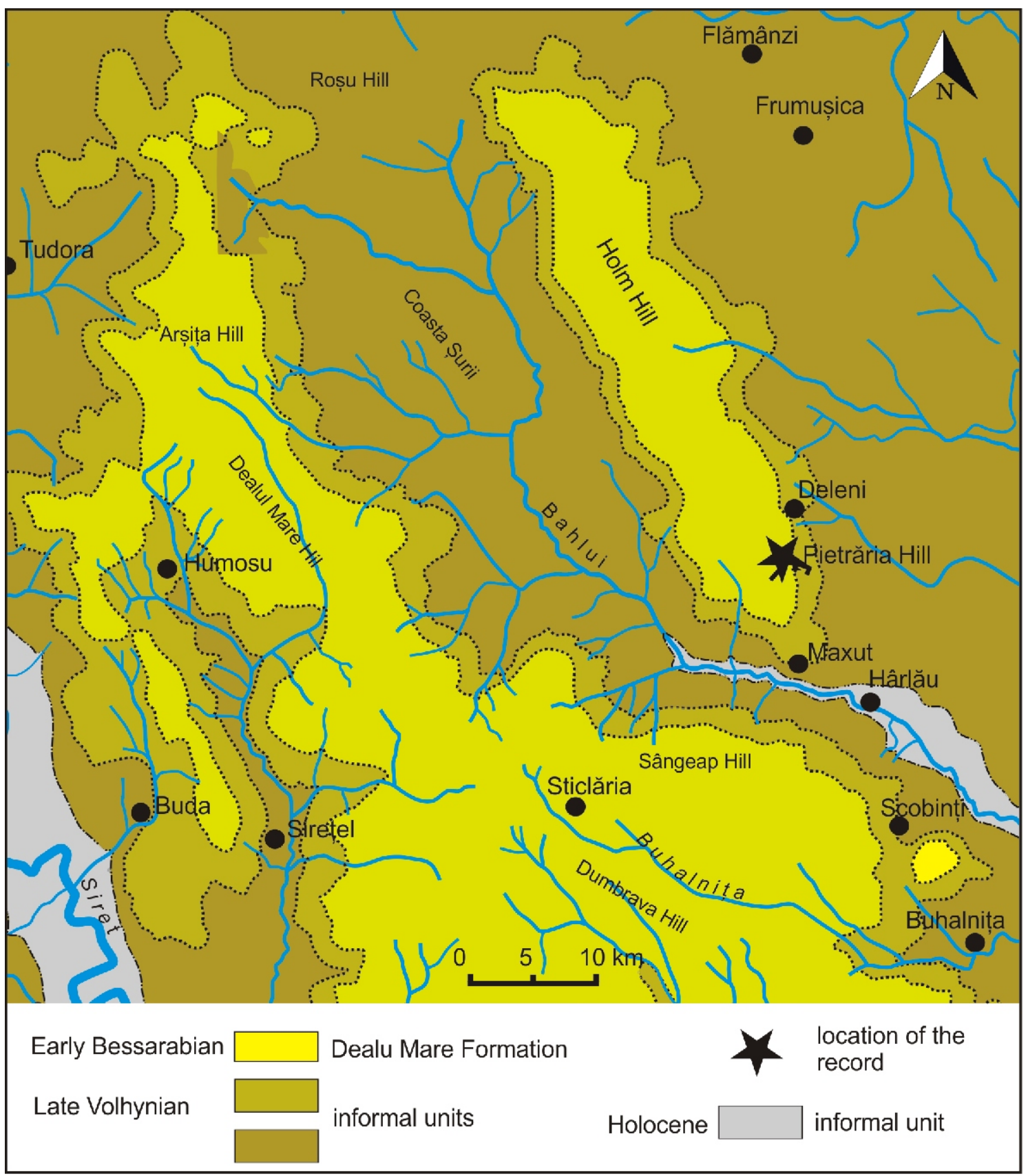

Fig. 4. Location of the Deleni deinothere specimen

Geological sketch of the Dealul Mare-Holm hills area, after lonesi (2006)

Taking into account the regional significance of the Congeria faunas for the Bessarabian of the Moldavian Platform, the deposits which host the deinothere remains belong to the Bârnova-Muntele Formation sensu Sinzov 1883 (Jeanrenaud 1967, 1971; Ionesi et al., 2005). From the biostratigraphic point of view, this formation is confined with the Mactra fabreana d'Orbigny, 1844, and Plicatiforma fittoni (d'Orbigny, 1844) Concurrent Range Zone (Ionesi et al., 2005), but typically has the peculiar fauna with small mactras (e.g., Mactra macarovicii Jeanrenaud, 1958) and weakly brackish to lacustrine molluscs (Congeria, Hydrobia, and Melanopsis, Neritina, Viviparus, respectively). It should be noted that, on the geological sketches made by lonesi et al. (2005: 329), these Bessarabian deposits were erroneously included in the Khersonian of brackish depositional environment, although the authors noted the confusion which can be provoked by the small mactrid faunas.

Moreover, the Bârnova-Muntele Formation continues to crop out towards the east prolonging on the Republic of Moldova territory. In the latter area, more frequent vertebrate records were described as the consequences of the larger area of the formation occurrence and more consistent sampling.

\section{GEOLOGICAL SETTING FOR THE SPECIMEN} FROM DELENI (IASSI COUNTY)

The description of the second specimen was published by Macarovici and Zaharia (1968). The fossil originated from the Early Bessarabian microconglomerate of the Pietrăria Hill 
Quarry (Deleni, laşi County, Figs. 1 and 4), where millstones for local usage were produced in the past. The historical approach of geological research of this area provided many successive data starting with the late 19th century until the recent days (see a detailed historical overview in lonesi, 2006).

In the area of Dealul Mare-Hârlău, Ştefan (1989) documented a sedimentary succession assigned to the Volhynian ( $\sim 260 \mathrm{~m}$ thick) and Bessarabian ( $200 \mathrm{~m}$ thick) according to the mollusc assemblages. Lithologically, sands and subordinate sandstones, oolites, and oolitic sandstones dominate over the clays and siliceous microconglomerates. Informal units with several lithological markers were proposed only, one of these being the Dealul Mare Microconglomerate, where the isolated molar was found. It displays 10-12 m thickness and develops structural plateaus at the highest elevations of the Dealul Mare and Holm hills (Fig. 4).

Later, lonesi et al. (2005) proposed the of Dealul Mare Formation for the entire Early Bessarabian succession on the right and left banks of the Siret River around the Fălticeni and Hârlău areas (Suceava and laşi counties) improving the correlation of the marker-levels proposed by Ştefan (1989).

However, the main discrepancies of the recent works (lonesi et al., 2005: 50, 179; Ionesi, 2006: 99-101) consist in the proposal of the formal lithological units following the rock ages. As an example, the end of Volhynian and the beginning of Bessarabian on both banks of the Siret River seem to be characterized by the same general lithology of a coastal palaeoenvironment, but the succession was divided into two formal units because it includes the Volhynian-Bessarabian boundary (lonesi et al., 2005).

Consequently, there are still details that need to be settled on the areal geology and on the formal lithological units, but the source of the deinothere molar is undoubtedly the Dealul Mare siliceous microconglomerate cropping out in the Pietrăria Hill Quarry, southern part of Holm Hill (Deleni, Fig. 4). Several molluscs have been identified within the clasts by Macarovici and Zaharia (1968) and Ştefan (1989), documenting accurately the Early Bessarabian age, respectively: Mactra vitaliana d'Orbigny, 1844, M. pallasi Baily, 1858, Tapes gregarius gregarius (Partsch, 1823), T. gregarius ponderosus (d'Orbigny, 1844), Granulolabium bicinctum (Brocchi, 1814), Dorsanum duplicatum (Sowerby, 1829), and Gibbula podolica insperata (Kolesnikov, 1930).

The litho- and biofacies point to a shelf palaeoenvironment with shallow supersaturated and high-energy waters (the oolitic levels according to Ştefan, 1989; lonesi et al., 2005; Ionesi, 2006). The mixture of brackish and terrestrial faunas encountered within the microconglomerates causes some uncertainties regarding the age of the molar, but the relatively well preservation proves a reduced transport (the breaking of disto-lingual part has been caused most probably by the sampling bias). Moreover, there are only Sarmatian outcrops in the area (the oldest are the Volhynian rocks followed by the Early and Late Bessarabian ones). Also, the youngest deposits in this northern part of platform are Late Bessarabian; a general emergence is documented after that. Consequently, the age of host rocks is improbable to be younger than Bessarabian.

\section{MATERIAL AND METHODS}

The material includes mainly the right mandible fragment of Deinotheirum giganteum (Kaup, 1829) housed at the MNS-IB Bacău (Museum of Natural Sciences “Ion Borcea”), Vertebrate collections, No.105, summarily mentioned by Şova (1963). A left tibia fragment was first added (Vertebrate collections,
MNS-IB 106). Taking into account that only few deinothere remains were collected from the outcrop, we suppose that it belongs to the same individual. The second specimen is an isolated M2 sin. stored in the MP-UAIC laşi (Museum of Paleontology - University of "Alexandru loan Cuza" laşi, Inv. No. MZS-9) mentioned by Macarovici and Zaharia (1968). These specimens represent the so far less known medium-sized deinotheres documented within the ECF system.

The left hemimandible fragment and the molars of Deinotherium giganteum were compared with the holotype proposed by Kaup $(1829,1832)$ and with similar specimens quoted in the most important scientific references. We furthermore compared our material to the other medium-sized deinotheres from Romania recorded to date. The material used consists of different molars, as well as fragments of maxilla and skeletal bones.

For comparison, a dataset of $D$. giganteum was selected confined mainly within the MN 9-MN 10 time span: Kaup (1829, 1832), Gräf (1957), Mottl (1970), Bachmayer and Zapfe (1976), Tobien (1988), Gasparik (1993, 2001), Huttunen (2002b), Böhme et al. (2012), and Pickford and Pourabrishami (2013). This way, we avoid the overlapping between the morphological features and biometrical values for the deinothere species owing to their continuous size increase with the geological age. Generally, the values of the biometric parameters are only indicative taking into account the incomplete Romanian deinothere remains.

We also took into account the Brusturi-Tătăruş specimen from the western part of Romania (Codrea, 1989; ?MN11-MN12) and the Bulgarian specimen of Aksakovo (Vergiev and Markov, 2010) without a certain age because they have been described from the areas adjoining the ECF.

The occlusal morphology follows the nomenclature proposed by Tassy (1996a) and the mandibular measurements were also taken after Tassy (1996b). The systematics follows Shoshani and Tassy (2005; Figs. 5-10).

The dental terminology for the tooth descriptions follows Tassy (1996a): m - lower molars; M - upper molar; $p$ - lower premolar; $\mathrm{m} 1$ - the tooth number, counted from the anterior; dext. - dexter; sin. - sinister; $L$ - length of the molar; $\mathrm{W}$ - width of loph/lophid; Et - enamel thickness; WL - ratio of the maximum width and length.

The cristid pattern description follows Pickford and Pourabrishami (2013) and Aiglstorfer et al. (2014). In the occlusal description, metalophid, hypolophid and tritolophid for the lower teeth, and protoloph and metaloph for the upper teeth are used.

Institutional abbreviations: MNS-IB - Museum of Natural Sciences "Ion Borcea" Bacău; MP-UAIC - Museum of Paleontology. Original collections: "Alexandru loan Cuza" University of laşi; MPS-UBB - Museum of Geology-Geography, "BabeşBolyai" University of Cluj-Napoca.

\section{SYSTEMATIC PALAEONTOLOGY}

Class Mammalia Linné, 1758

Order Proboscidea Illiger, 1811

Sub-order Deinotheroidea Osborn, 1921

Family Deinotheriidae Bonaparte, 1845

Genus Deinotherium Kaup, 1829

Deinotherium giganteum Kaup 1829

(Figs. 5 and 8) 

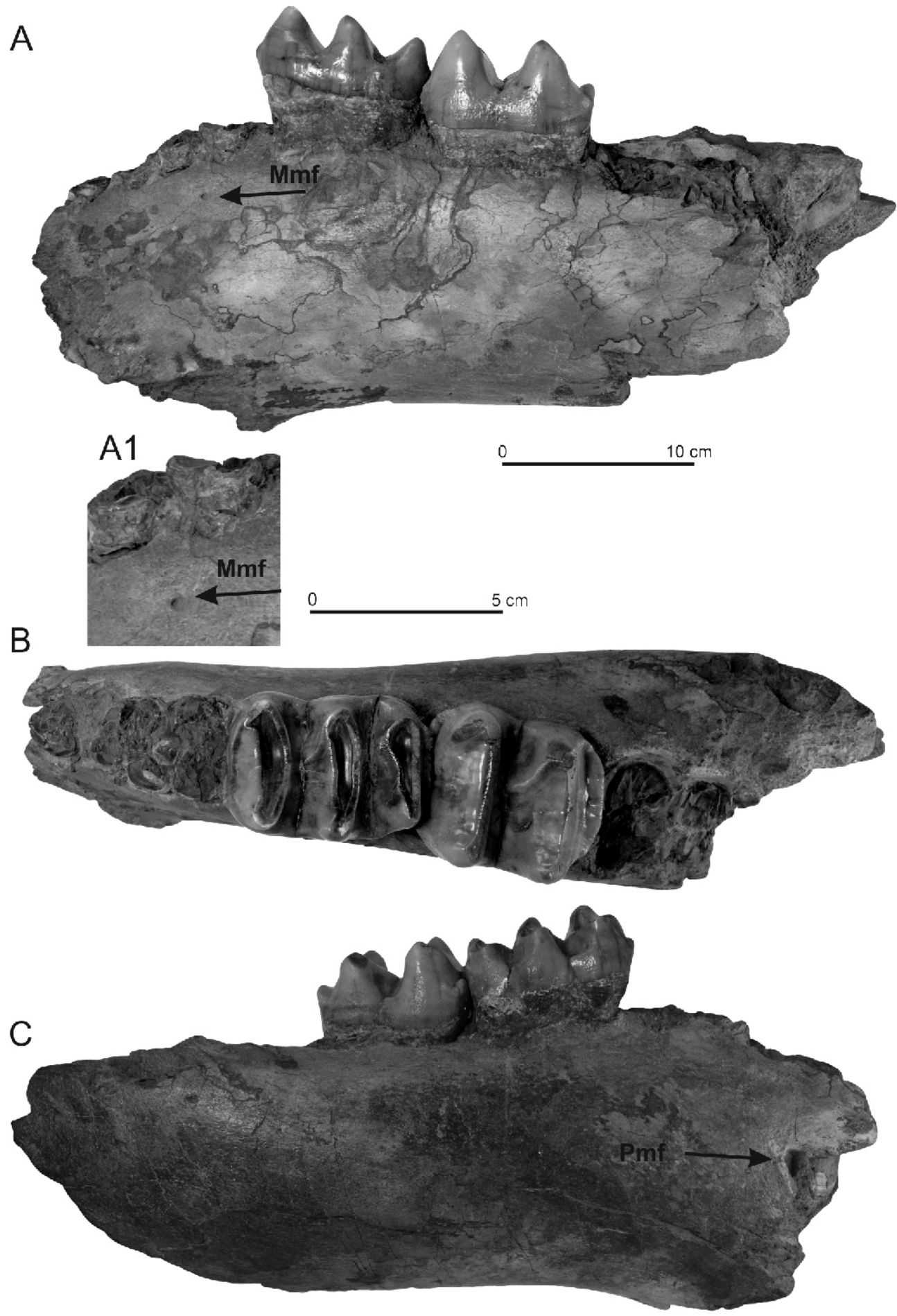

Fig. 5. Deinotherium giganteum from Drăgeşti (Bacău County), Eastern Carpathians Foreland, Romania

Right hemimandible fragment (MNS-IB 105): A - lingual view; B - occlusal view; C - buccal view; $\mathrm{mmf}$ - medial mental foramen, pmf - posterior mental foramen; A, B, C - scale bar 0-10 cm; A1 scale bar $0-5 \mathrm{~cm}$

Material of Drăgeşti ( B a c ău C ount y ). Right hemimandible representing the mandibular body, devoid of both proximal and distal parts. The toothrow includes the well-preserved $\mathrm{m} 1-\mathrm{m} 2$, the roots of $\mathrm{p} 3-\mathrm{p} 4$ and $\mathrm{m} 3$ nested in the alveoli; a proximal fragment of tibia has also been recovered (Fig. 8). The material does not show signs of reworking, the fragmentary aspect results most probably during the extraction from the host-rocks.
L o c a l i t y. - Drăgeşti (Vaslui County).
A g e. - Vallesian (MN 9) - Late Bessarabian. 
Mandibular measurements of the Drăgeşti specimen (measurements follow Tassy, 1996b)

\begin{tabular}{|c|c|c|c|c|c|}
\hline \multirow{2}{*}{ Parameter } & Dr. & Breit. & Haus. & Kettl. & Laeer. \\
\hline & \multicolumn{5}{|c|}{$[\mathrm{mm}]$} \\
\hline Maximum length of fragment on horizontal line & $\sim 447.5$ & 1100 & - & - & - \\
\hline $\begin{array}{l}\text { Mid-alveolar length taken on the buccal side between the anterior } \\
\text { alveolus (p3) and the m3 root }\end{array}$ & $\sim 375.5$ & 374 & 345 & 391 & 317 \\
\hline Width of the horizontal ramus taken under $\mathrm{m} 1$ & 65 & - & - & - & - \\
\hline Width of the horizontal ramus taken at the posterior part of the tooth row & 124.8 & - & - & - & - \\
\hline $\begin{array}{l}\text { Height of the horizontal ramus taken posteriorly of p4 (in front of p4 the } \\
\text { lower mandibular border is broken) }\end{array}$ & 175.9 & $\begin{array}{c}\text { If. } \\
\text { p4 = 189; } \\
\text { m3 = } 146\end{array}$ & $\begin{array}{c}\text { If. } \\
\text { p4 }=255 \\
\text { m3 }=165\end{array}$ & $\begin{array}{c}\text { If. } \\
\text { p4 }=252 \\
\text { m3 }=176\end{array}$ & - \\
\hline The depth of alveolus for $\mathrm{p} 3$ & 88 & - & - & - & - \\
\hline
\end{tabular}

Dr. - Drăgeşti specimen, Breit. - Breitenfeld (Mottl, 1969); Haus. - Hausmannstteten (Mottl, 1969); Kettl. - Ketllasbrunn (Bachmayer and Zapfe, 1976); Laeer. - Laaerberg-Vienna (Huttunen, 2002b); If. - in front of

Collection. - The fossil remains are housed at MNS-IB Bacău, MNS-IB 105 (hemimandible fragment, Fig. 5), MNS-IB 106 (tibial fragment, Fig. 8).

General description. - The hemimandibular body is almost straight and displays the maximum height in front of $\mathrm{m} 1$ being slightly flattened laterally (Fig. 5 and Table 1). On the buccal side of the corpus the oblique line finishing into a broken orifice is visible, which is situated under p3 (Fig. 5C). It would represent the posterior mental foramen (Pmf). On the lingual side, a barely noticeable opening under p4 (Fig. 5A, A1) would correspond to the medial mental foramen (Mmf). It should be noted that this third foramen was mentioned so far only for the Subfamily Elephantinae (Ferreti and Debruyne, 2011: 399). Its small diameter is comparable to the modern Loxodonta africana (Blumenbach, 1797), but it is placed higher on the mandibular body as compared to all the taxa selected by Ferreti and Debruyne (2011: fig. 9). Consequently, this peculiar feature of the proboscidean mandibular canal and foramina should be also searched among the deinothere specimens.

Ge ne ra I c o m pari s o n. - Kaup $(1829,1832)$ proposed the genus Deinotherium based on a hemimandible sin. fragment with an incomplete ramus, but including the symphysis and the tusks, partially (tab. IV, fig. 1, 2 and add. tab. I, fig. 5; Da Din. 466 of Eppelsheim). Two other mandibles have been also recorded (add. tab.1, figs 1, 4-Da. Din. 467 sin. and add. tab. 2, figs. $1 \mathrm{a}, \mathrm{b}-\mathrm{Da}$ Din. 464 sin.) showing more morphological details (condylar and coronoid processes, foramina, symphysis etc). The general morphology of Drăgeşti specimen is similar to these records, including some biometric data (e.g., the height of the mandibular body for the Kaup's material is close to the Romanian specimen, respectively $170 \mathrm{~m}$ under $\mathrm{p} 4$ and $160 \mathrm{~mm}$ under m3 - the measurements after Gräf, 1957), but a more detailed metric comparison is hindered taking into account the smaller fragment of hemimandible found in Romania.

Mottl (1969), Bachmayer and Zapfe (1976) described more complete mandbiles of Early Pannonian age from the Austrian Breitenfeld, Holzmannsdorfberg and Kettlasbrunn localities, respectively. Consequently, taking into account the smaller fragment of the right hemimandible from Drăgeşti, an accurate comparison cannot be done. Nonetheless, it should be noted the separation of the anterior "crushing battery" p3-m1 (after Harris, 1973) and the posterior "shearing battery" m2-m3 (after Harris, 1973) for the specimens from Breitenfeld and Drăgeşti. Interestedly, the obtuse angle between the "crushing battery" and "shearing battery" is open towards the lingual side for the Drăgeşti toothrow, contrary to the opening towards the buccal side for the right hemimandible of Breitenfeld (Mottl, 1969: tab. XVII). Both toothrows of the mandible from Kettlasbrunn are almost straight. The compared mandibles seem to have the maximum height under p4 or under p4-m1 (Mottl, 1969: tab. XVI; Bachmayer and Zapfe: 1976: tab. II; Drăgeşti specimen: Fig. 5A).

The left hemimandible of Deinotherium giganteum of Pontian age, described by Codrea (1989), preserves several morphological features better than the Drăgeşti specimen (e.g., both anterior and posterior mental foramina are obvious on the buccal side).

Huttunen (2002b) illustrated a smaller left hemimandible fragment than of the Drăgeşti specimen, with p3-m2 (NHMW 2000z0038/0000) from probably Pannonian sands (Belvedere Sand) of Laaerberg (Vienna). The smaller-sized Austrian specimen has similar separation between the two functional batteries, but also displaying a contrary angle in comparison with the Drăgeşti specimen and the Breitenfeld mandible (Huttunen, 2002b: 258-259). The buccal side of the Laaerberg specimen also preserved the posterior mental foramen (Huttunen, 2002b: pl. 4, fig. 1).

For the metrical comparison, the hemimandible with complete and almost complete toothrows of the similar age were selected: Mottl (1969); Bachmeyer and Zapfe (1976); Huttunen (2002b) - Table 1.

\section{TOOTHROW OF RIGHT HEMIMANDIBLE - ROOTS OF P3-P4, M3}

The p3 has a broad-triangular shape and it seems to display one strong oval-triangular root on the mesial and one on the distal side. The disto-buccal sector is unclear. It cannot be assessed if there is or not a connection between the protoconid and metaconid. Generally, the p3 shape is triangular or triangular-oval for all the D. giganteum specimens (Moroşan, 1936; Mottl, 1969, 1970; Bachmayer and Zapfe, 1976; Tobien, 1988; Codrea, 1989; Gasparik, 1993, 2001; Huttunen, 2002b). The intraspecific variation consists in the variable dimensions and in the conid development, when the premolars are well-preserved.

The p4 of Drăgeşti is slightly trapezoidal-shaped. The metalophid and hypolophid seem to have continouos transversal roots. The protoconid and metaconid roots expose oval outlines, which are obliquely aligned to the axis of the tooth and connected in the midlle part. The hypolophid root is stronger than the first lophid and the shapes of hypoconid and entoconid narrow transversally. The p4 outline fits into the more diverse shape of the similar premolars, from almost square 
Table 2

Biometric values of the $\mathrm{m} 1$ and $\mathrm{m} 2$ (all values in $\mathrm{mm}$ ) Drăgeşti specimen of Deinotherium giganteum

\begin{tabular}{|c|c|c|c|c|c|c|}
\hline \multirow{2}{*}{ Tooth } & \multirow{2}{*}{ L } & \multicolumn{3}{|c|}{ Width of lophids $(1-3 ; 1-2)$} & \multirow{2}{*}{$\begin{array}{c}\mathrm{WL}= \\
\operatorname{maxW} / \mathrm{L}\end{array}$} & \multirow{2}{*}{ Et } \\
\hline & & W1 & W2 & W3 & & \\
\hline $\mathrm{m} 1$ & 88.2 & 62 & 63 & 60.7 & 0.7142 & $3.9-4.2$ \\
\hline $\mathrm{m} 2$ & 77.8 & 73.6 & 72.5 & - & 0.9460 & ?3.9-4.2 \\
\hline
\end{tabular}

(e.g., Mottl, 1969, 1970; Aiglstorfer et al., 2014) to quadrangular (e.g., Bachmayer and Zapfe, 1976; Tobien, 1988; Gasparik 1993, 2001) or slightly- trapezoidal-shaped (e.g., Tobien, 1988: fig. 25; Huttunen, 2002b).

The $\mathrm{m} 3$ seems to have two strong roots under the both lophids (the disto-lingual part of the $\mathrm{m} 3$ roots is broken). The buccal root of the first one is bigger than on the lingual side. The enamel thickness is difficult to assess. Generally, the tooth pattern is similar to the correspondent tooth of the European records (Mottl, 1969, 1970; Bachmayer and Zapfe, 1976 Gasparik, 1993, 2001; Huttunen, 2002b; Pickford and Pourabrishami, 2013, among others).

Description of $\mathrm{m} 1$. The crown is subrectangular trilophodont and moderately worn. The hypolophid is the widest one and the tritolophid is the narrowest one. The lophids are generally smaller and wider on the buccal side than on the lingual one (Fig. 5B and Table 2).

The metalophid is slightly concave messialy with approximately equally developed protoconid and metaconid. Two distinct anterior cristids run from the protoconid and metaconid ending in the damaged anterior cingulid. The praemetacristid is blunt, unlike the praeprotocristid which is strong and narrow. Only a weak postprotocristid can be observed (Fig. 5B). The hypolophid also exhibits well-developed conids, from where an inferred praeentocristid and a strong praehypocristid reach the anterior valley. The tritolophid shows a more worn conid on the buccal side than on the lingual one; it develops moderate cristids.

The mesial slope of both anterior (first) and posterior (second) valleys is more tilted. A deeper and wider groove can be observed on the buccal side of anterior valley than on the posterior one (Fig. $5 \mathrm{C}$ ). The anterior and posterior cingulids are very narrow, the latter being very finely wrinkled. The lateral cingulid can be observed only on the valleys, especially on the buccal side where very small tubercles occur. A remarkable pressure mark can be deduced on the tooth distal side. The enamel thickness varies between 3.9 and $4.2 \mathrm{~mm}$.

Comparisons of $\mathrm{m} 1$. The overlapping of morphological features and biometrical values and the time-averaged deinothere assemblages (e.g., MN4/5-MN 11 in the Mainz Basin) determined the researchers to focus on records with absolute age or accurate biostratigraphic constraints of tooth-bearing layers (Böhme et al., 2012; Pickford and Pourabrishami, 2013). This calibration is the solution to solve the overlapping of metric data which occur in some cases and also do not expand the range of biometric variation over the real evolution of species in time.

Consequently, for comparison, this tendency has been followed selecting specimens from Kaup (1929, 1932), Gräf (1957), Mottl (1969, 1970), Bachmayer and Zapfe (1976), Tobien (1988), Huttunen (2002b), and Pickford and Pourabrishami (2013: only some MN 9-MN 10 specimens from Bremersheim, Dintesheim and Wallerteim). Aiglstorfer et al.
(2014) has also been followed, who noted that the specimens of Frohnstetten are Late Miocene in age.

As we already mentioned, the specimens from the western part of Romania (MN 11-MN 12) and the Bulgarian specimen of Aksakovo without a certain age were used because they were described from the areas adjacent to the ECF.

First of all, the $\mathrm{m} 1$ Drăgeşti fits well in morphology with the molar described by Kaup (1832: tab. V, fig. 3), considering the degree of wear is advanced in the former specimen. The general lophid and cristid pattern, the more inclined mesial slope of lophids accentuated tilted of mesial slope lophids, the deeper groove on the buccal side of anterior valley, and the narrow distal cingulid are the common features. The differences occur in the suppressed anterior cingulid, the weakly lateral one, and the more obvious anterior cristid of lingual tritoloph conid in the Romanian molar. Similar morphology is displayed by the molars figured in Kaup (1832: tab. III, figs. 7, 8, 9; add. tab. I, figs. 1, 4; add. tab. II, figs. 1, 1a). The smallest width of lophids oscillates in these molars (first, second or third one).

Secondly, the $\mathrm{m} 1$ of Drăgeşti shares close morphological affinities with the European specimens of $D$. giganteum: the occlusal morphology is conservative, and the intraspecific variation appears in the lophid widths and sculptural cristids, valley and cingulid development, and accessory or cingular cusplets.

Near the study area, Moroşan (1936) described an $\mathrm{m} 1$ from the Late Sarmatian sands cropping out at Teleneşti (Orhei County, Republic of Moldova). Unfortunately, only the molar's metalophid was complete and appropiate comparison cannot be done.

However, the occlusal morphology of the Drăgeşti specimen is similar with the $\mathrm{m} 1 \mathrm{sin}$. and dext. from the complete toothrow of the Breitenfeld, Holzmannsdorfberg and Kettlasbrunn mandibles (Mottl, 1969, 1970; Bachmayer and Zapfe, 1976, respectively). The largest second lophid, the cristid pattern, the weak lateral cingulid, the strong pressure marks can be noted as common features although the stage of wear is variable.

The $\mathrm{m} 1$ from Drăgeşti also exhibits a common occlusal pattern with the m1s figured by Tobien (1988) from Montredon. Instead, the shapes of the French specimens vary from quadrangular (pl. 5, m1 from the toothrow of figs. 23-25) to slightly trapezoidal (pl. 3, fig. 18).

Gasparik $(1993,2001)$ assigned two similar $\mathrm{m} 1 \mathrm{sin}$. (V.1105 $7 \mathrm{HGI}$ and V.11055 HGI) from the Boór's sand pit at Sopron to $D$. giganteum. From Pécs, a left hemimandible with $\mathrm{m} 3$ and an alveoli for p4-m2 (HGI Ob-2994) was also quoted. All the fossils were assigned to the Pannonian (Vallesian, MN 9). For m1, no biometric data has been mentioned (Gasparik, 1993, 2001). It should be noted that Aiglstorfer et al. (2014) assigned the Sopron Boór's sand pit specimens to " $D$. levius".

The main difference between the $m 1$ of Drăgeşti and the $m 1$ from Lower Austria and Burgenwald (Huttunen, 2002b) is the weaker development of anterior cristids. Otherwise, the occlusal morphology is similar, including the cingulid pattern.

A difference of $\mathrm{m} 1$ described by Codrea (1989) form the Pontian hemimandible sin. (GMGGD 15526) of BrusturiTătăruş, Bihor County (consequently not in the focused time-span), is the trapezoidal-elongated shape as consequence of the biggest tritolophid.

Comparative molar is the $\mathrm{m} 1 \mathrm{sin}$. described by Vergiev and Markov (2010) from Aksakovo locality (NE Bulgaria), belonging to the toothrow of left hemimandible. The small differences consist in the lophid widths, cristid pattern and conid development. 


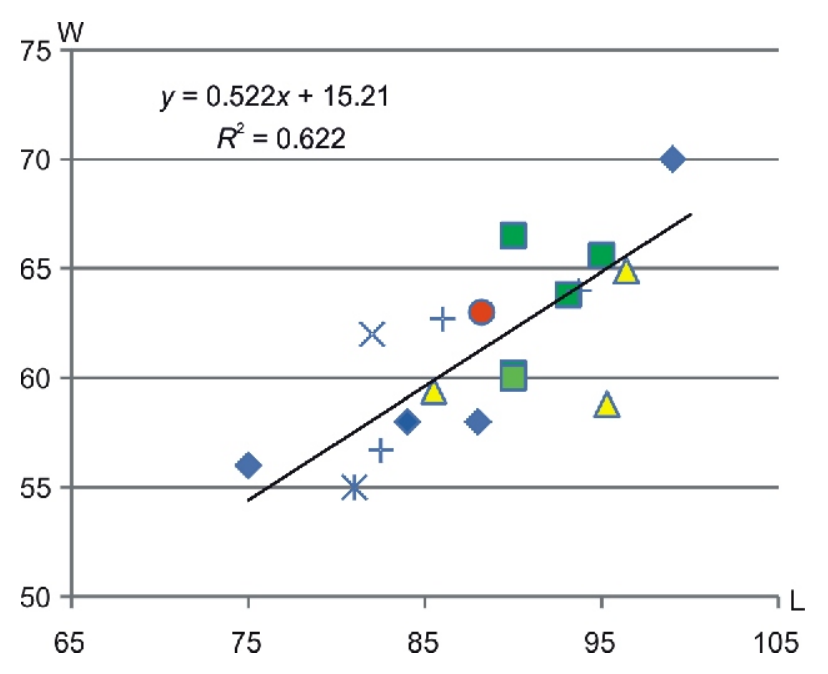

Fig. 6. Scatter diagrams of $\mathrm{m} 1$ (maximum length versus maximum width of lophids) for the compared deinothere specimens

The selected specimens and the length-width values are listed in Appendix 1; circle - Drăgeşti, triangle - Eppelsheim (Gräf, 1957), square - Montredon (Tobien, 1988), rhombus - LeithagebirgeMannesdorf bei Angern (Huttunen, 2002b), + - according to Pirckford and Pourabrishami (2013), other sings - Teleneşti, Breitenfeld, Kettlasbrunn (Moroşan, 1936; Mottl, 1969; Bachmayer and Zapfe, 1976)

For biometrical comparison, the same dataset is selected (as for the occlusal morphology) confined mainly with the MN 9-MN 10 time span (see Appendix 1*).

The $\mathrm{WL}$ ratio $(\mathrm{Mw} / \mathrm{L})$ placed the $\mathrm{m} 1$ approximately in the middle of the selected specimens between the miminum and maximum values (Fig. 6), respectively 0.0616999 (Da Din 467 sin.) Eppelshiem (Gräf, 1957), and 0.756098 of Kettlasbrunn (Bachmayer and Zapfe, 1976). Metrically, the $\mathrm{m} 1$ is close to the specimens from Bermesheim, Kettlasbrunn and several specimens from Montredon (see Appendix 1).

Accordingly, the isolated teeth or fragmentary mandibles and maxillaries with complete or incomplete toothrows must be assigned to the species using the metric analysis correlated with well biostratigraphic constraints (Böhme et al., 2012; Pickford and Pourabrishami, 2013; Aiglstorfer et al., 2014 among others). The sexual dimorphism was also invoked for the metric variation of similar fossil molars, but the distinction of sexes only on the teeth biometry is not yet solved (Pickford and Pourabrishami, 2013) as for other skeletal parts of proboscideans (e.g., Haynes, 1991; Smith and Fisher, 2013). It should be noted that a quantitative assessment of recent elephant dentition concluded that the males tend to have larger teeth than females, and the toothrows fluctuate more consistent in length and width as compared to other mammals (Roth, 1992).

Description of $\mathbf{m} 2$. The crown consists of two almost unworn and straight lophids. They have approximately the same width, with the crown tending to a square shape in occlusal view (slightly longer than wide). The metalophid develops a strong praeprotocristid and a blunt praemetacristid, unlike the hypolophid, which exhibits only a strong praehypocristid extending to the valley (Fig. 5B). The buccal conids are smaller than the lingual ones, both having the enamel slightly damaged messially. The anterior cingulid is narrowed by the contact to the anterior tooth, only a small tubercle being observed on the buccal side. The finely wrinkled posterior cingulid is more developed than the anterior one. A pressure mark can be only deduced on the distal side. The enamel seems to be of the same thickness with the $\mathrm{m} 1$ (Table 2).

Comparisons of $\mathbf{m} 2$. The $\mathrm{m} 2$ of Drăgeşti shows general similarities with the correspondent molar of the specimen described by Kaup (1829, 1832: tab. IV, fig. 1, 2 and add. taf. I, fig. 5; Da Din. 466 of Eppelsheim). As differences, the Drăgeşti specimen exhibits the obvious posterior cingulid, the strong praehypocristid, and the slopes of valleys seem to be more tilted. A strong morphological similarity could be also retaining in comparison with the $\mathrm{m} 2$ figured in add. taf. I, figs. 1, 4 and add. taf. II, fig. 1.

The $\mathrm{m} 2$ sin. and dext. figured by Mottl $(1969,1970)$ from Breitenfeld and Bachmayer and by Zapfe (1976) from Kettlasbrunn also exhibit close morphology with the $\mathrm{m} 2$ Drăgeşti, including the presence of praehypocristid and posterior cingulid. As differences, the hypolophid of the $\mathrm{m} 2 \mathrm{sin}$. of Breitenfeld is bigger than the metalophid. Huttunen (2002b) outlined the peculiarity of the $\mathrm{m} 2 \mathrm{sin}$. and dext. of Kettlasbrunn by "the possible traces of cavities" and the "deep circular depression" placed medially in both valleys.

The isolated $\mathrm{m} 2$ (pl. 3, fig. 19) figured by Tobien (1988) from Montredon have more trapezoidal outline, the hypolophyd being also bigger than the first lophid. On the complete toothrows (pl. 5, figs. 23-25) the metalophid has the maximum width. The occlusal pattern is similar with the $\mathrm{m} 2$ Drăgeşti, taking into account several intraspecific variations on the French material: the lateral cingulid cusplets (pl. 2, fig. 12; pl. 3, fig. 19), the presence of praeentocristid (e.g., pl. 3, fig. 19), and the various developments of anterior and posterior cingulids.

The $\mathrm{m} 2$ of Drăgeşti proves close similarities to the corresponding molars described by Huttunen (2002b) from Lower Austria and Burgenwald. It should be noted the similar cristid pattern: from each conid sloping down on the valley an anterior cristid. The wide posterior cingulid (e.g., NHMW la.8.b.46 Wilfersdorf, pl. 3, fig. 4) is a peculiar feature (like a smaller third lophid).

The $\mathrm{m} 2$ sin. from the mentioned Pontian mandible (Codrea, 1989) shows similar morphology as the Drăgeşti specimen, having a more elongated outline instead.

The Bulgarian specimens (VRMH 164: L-80; W-69/70) and dext. (VRMH 166: L-80; W-70/70) referred to Deinotherium giganteum of Aksakovo by Vergiev and Markov (2010) tend to be square in shape. The former specimen displays a weak praeprotocristid and a very strong praehypocristid (the metaconid and entoconid area being slightly damaged). The VRMH 166 is more worn and damaged on the buccal side; the weak anterior cristids of the metaconid and entoconid is observed. For both the $\mathrm{m} 2$ specimens, the anterior cingulid is also inferred, but the distal one is wider compared to the Drăgeşti molar.

The metric analysis took into account the previous records (except for the Brusturi-Tărăruş and Bulgarian specimens, without certain ages), and additionally the Hungarian specimens (m2 sin. HGI V11059 and m2 dext. HGI V11056, after Gasparik (1993, 2001; Fig. 7 and Appendix 1). 


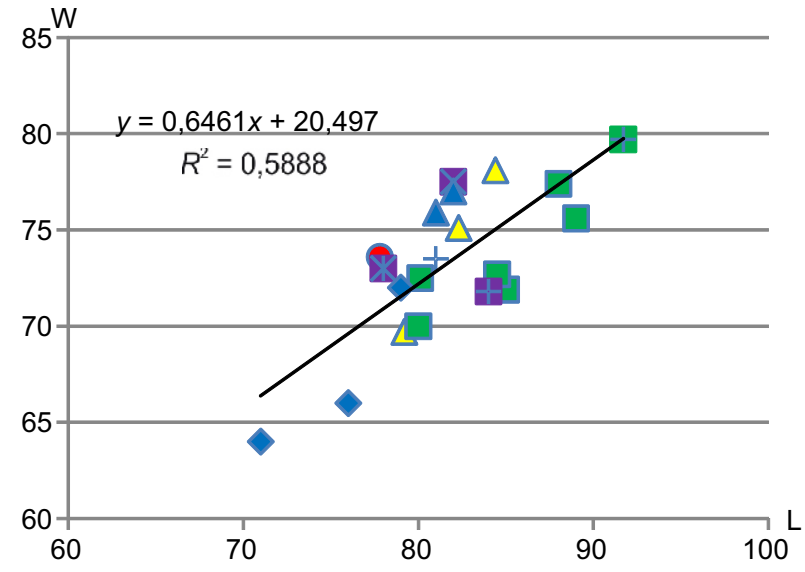

Fig. 7. Scatter diagrams of $\mathrm{m} 2$ (maximum length versus maximum width of lophids) for the compared deinothere specimens

The selected specimens are listed in Appendix 1; circle - Drăgeşti, yellow triangle - Eppelsheim (Gräf, 1957), blue triangle - Sopron (Gasparik, 1993); square - Montredon (Tobien, 1988); rhombus Altmannsdorf-Wielfersdorf (Huttunen, 2002b), + - according to Pirckford and Pourabrishami (2013), other sings - Breitenfeld, Kettlasbrunn (Mottl, 1969; Bachmayer and Zapfe, 1976)

The biometric values for the $\mathrm{m} 2$ Drăgeşti are close to the Kettlasbrunn (Bachmayer and Zapfe, 1976), Breitenfeld (Mottl, 1969) and Sopron specimens (Figs. 4 and 7, Appendix 1). The $\mathrm{WL}=0.946015$ (Table 2) is the biggest one, comparable in its tendency to the square shape with the Kettlasbrunn and Bulgarian specimens (see Appendix 1).

In conclusion, the morphological and biometrical data of $\mathrm{m} 1$ and $\mathrm{m} 2$ fit in with the most important specimens mentioned above and allow ranking the fragmentary mandible to $D$. giganteum.

TIBIA SIN.

Description of the tibial fragment. The tibia sin. preserves only the proximal epiphysis and a fragment of the diaphysis (Fig. 8) restored after it has been broken during the sampling. The tibial tuberosity shows antero-laterally a massive protrusion, from where the tibial crest gets down vaguely becoming stronger to the middle of the shaft. The tibial crest has a remarkable medial inclination (Fig. 8B). Down of the epiphysis, the bone becomes triangular in cross-section. The interosseous and medial margins are well-developed (Fig. 8C). Towards the distal part, the shaft tends to approximate a round cross section, and the broken transversal section exhibits the cancellous/spongy mass filling the bone (Fig. 8E).

The tibial proximal epiphysis exhibits a slightly developed intercondylar eminence, with the medial and lateral tubercles also less pronounced (Fig. 8A). The medial condyle is slightly higher than the lateral one (Fig. 8B). The articular facets are generally moderately concave (the depth of the medial and lateral articular facets is $\sim 18.10$ and $\sim 21.06 \mathrm{~mm}$, respectively) and oval-quadrangular in outline. The medial facet enlarges cranially, where it also forms a slight sinus near the anterior intercondylar area. The lateral one is smaller, with expressed concavity of the dorsal outline in comparison with the plantar one, which is almost straight. Between these two articular facets, the intercondylar sulcus is narrowed, slightly curved, and centrally elevated, with a larger and deeper anterior intercondylar area than the posterior one. The oval-triangular popliteal notch can be observed towards the plantar side of proximal epiphysis (Fig. 8A, C).

The plantar side (Fig. 8C) is outlined by an almost vertical lateral margin which slightly extends laterally towards the distal part. The interosseous border is conspicuously concave near the proximal epiphysis to become almost straight further on. The fibula articular facet is oval, with an abraded portion towards the proximal-lateral direction (Fig. 8C). One cannot observe the nutrient foramen because of the bone damages, most probably. The biometric parameters are listed in Table 3.

Comparison of tibial fragment. There are few tibia of Deinotherium giganteum mentioned in the available literature. Moroşan (1936) listed a proximal short fragment of tibia assigned to "D. gigantissimum" collected from Sarmatian rocks of the Pătruja Valley (Volcineş, Republic of Moldova) and currently housed at the Natural History Museum Khisinev. Later, Codrea (1989) reported a complete tibia sin. (MPS UBB: GMGGD 16257) from the Pontian of Brusturi-Tătăruş (Bihor County).

The Drăgeşti tibia sin. features the common rectangular outline of medial and lateral articular facets of proximal epiphysis for the Deinotherium. The anterior/dorsal enlargement of medial articular facet and the uncommon sinus of lateral articular facet outline (Fig. 8A) should be noted as specific features for the Drăgeşti specimen. The well-delimited intercondylar

Measurements of the tibial fragment sin. of the Drăgești specimen and the metrical comparison with the similar bone of several deinothere specimens

\begin{tabular}{|l|r|c|c|c|c|c|}
\hline \multirow{2}{*}{\multicolumn{1}{|c|}{ Parameters }} & \multicolumn{2}{c|}{ D. giganteum } & \multicolumn{4}{c|}{ D. proavum } \\
\cline { 2 - 7 } & Dr. & Br.-T. & Mân. & Pik. & \multicolumn{2}{c|}{ Ezer. } \\
\hline Maximum length of the fragment & $? 417.2$ & 840 & 920 & 950 & 1200 & 1250 \\
\hline Maximum medio-lateral diameter of proximal epiphysis & 203.2 & 275 & 330 & 310 & 370 & 365 \\
\hline Width of the facies articulares proximales & 196.4 & 263 & - & - & & \\
\hline Maximum dorsal-plantar diameter of proximal epiphysis & 152.8 & - & - & - & 320 & 320 \\
\hline Minimum width of diaphysis & 93.7 & & - & - & - & - \\
\hline Maximum width of diaphysis & $\sim 107.1$ & 119 & 140 & 160 & 160 & 165 \\
\hline
\end{tabular}

Dr. - Drăgeşti; Br.-T. - Brusturi-Tătărus, according to Codrea (1989); Mân - Mânzaţi - "D. gigantissimum", according to Ştefănescu (1910); Pik. - Pikermi (Greece) - "D. giganteum", according to Gaudry (1862-1867); Ezer. - Ezerovo (Plovdiv County) - "D. thraciensis" - according to Kovachev and Nikolov (2006); the specimen represents D. proavum according to Codrea and Margin (2009) 


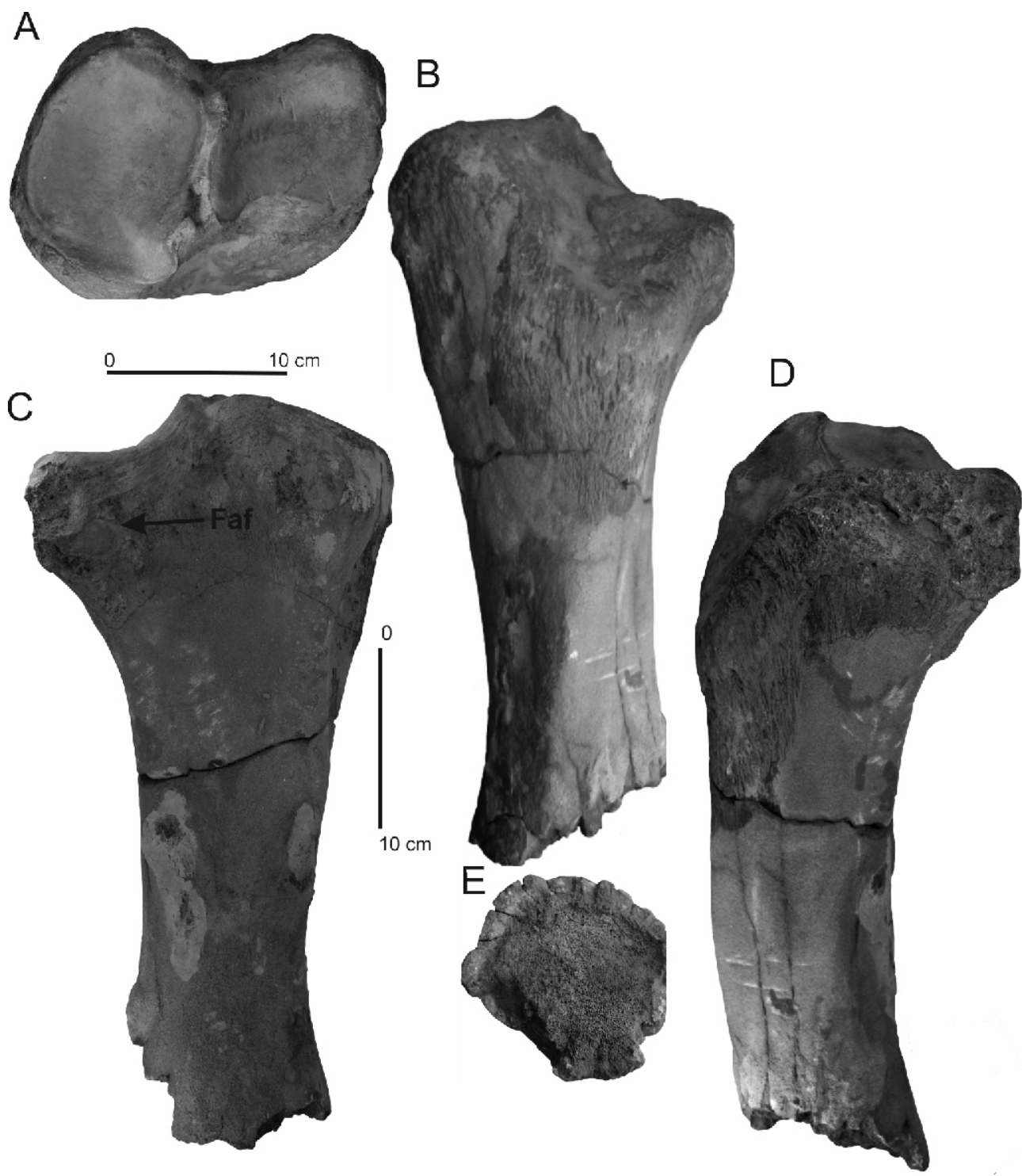

Fig. 8. Deinotherium giganteum from Drăgeşti (Bacău County), Eastern Carpathians Foreland, Romania

Tibia sin. fragment: A - proximal view; B - dorsal view; C - plantar view, Faf - fibula articular facet; D - lateral view; E - distal view

sulcus, tubercles and polipteal notch could be also pointed out. The fibula articular facet is oval outlined in comparison with the Prodeinotherium bavaricum (Huttunen and Göhlich, 2002: 508 ), on which it is supossed to be round. The tibial tuberosity is situated lower on the bone, showing a massive development.

The metric analysis shows smaller values for the Drăgeşti tibia in comparison with the similar specimen from BrusturiTărăuş (Codrea, 1989). Taking into account that tibia shows a typical morphology for the deinotheres, two issues are arising: why it shows smaller dimensions than the tibia from Brusturi-Tătăruş, and whether it belongs to the same specimen as the hemimandible fragment or not. The tibia size could be explained by the different ontogentic stage of the specimens taking into account that the growth and the fusion of the skeletal bones in the recent proboscidiens is not linearly related as the growth and tooth progression (Roth, 1984). The author demonstrated that the fusion of epiphyses to the diaphyses of long bones appears to be concentrated within a short span of time and it may occur at different times in different individuals or in the two sexes. Secondly, only skeletal remains belong to the deinotheres that were collected from the Drăgeşti outcrop, and we suposse that they originate from a single individual.

DEINOTHERIUM GIGANTEUM SPECIMEN
FROM THE PIETRĂRIA HILL OUARRY (FIG 9)

Material of Deleni (I aşi County). - M2 $\sin$.

L o c a I i t y. Pietrăria Hill Ouarry (Deleni, laşi County)

A g e. Vallesian of Eastern Europe (?MN 7-8-MN 9) - Early Bessarabian.

C o Il e c t i o n. The molar is housed in MP-UAIC, Inv. nr. MZS-9.

Description of M2. Macarovici and Zaharia (1968) pointed out correctly the main features of relatively worn M2 sin., which is redescribed here: the loph convexity towards the mesial side, the strong anterior and posterior cingulum, the well-developed posthypocrista, and the disto-lingual damage of hypocone. The roots are missing. The authors also mentioned the biometrical values. 

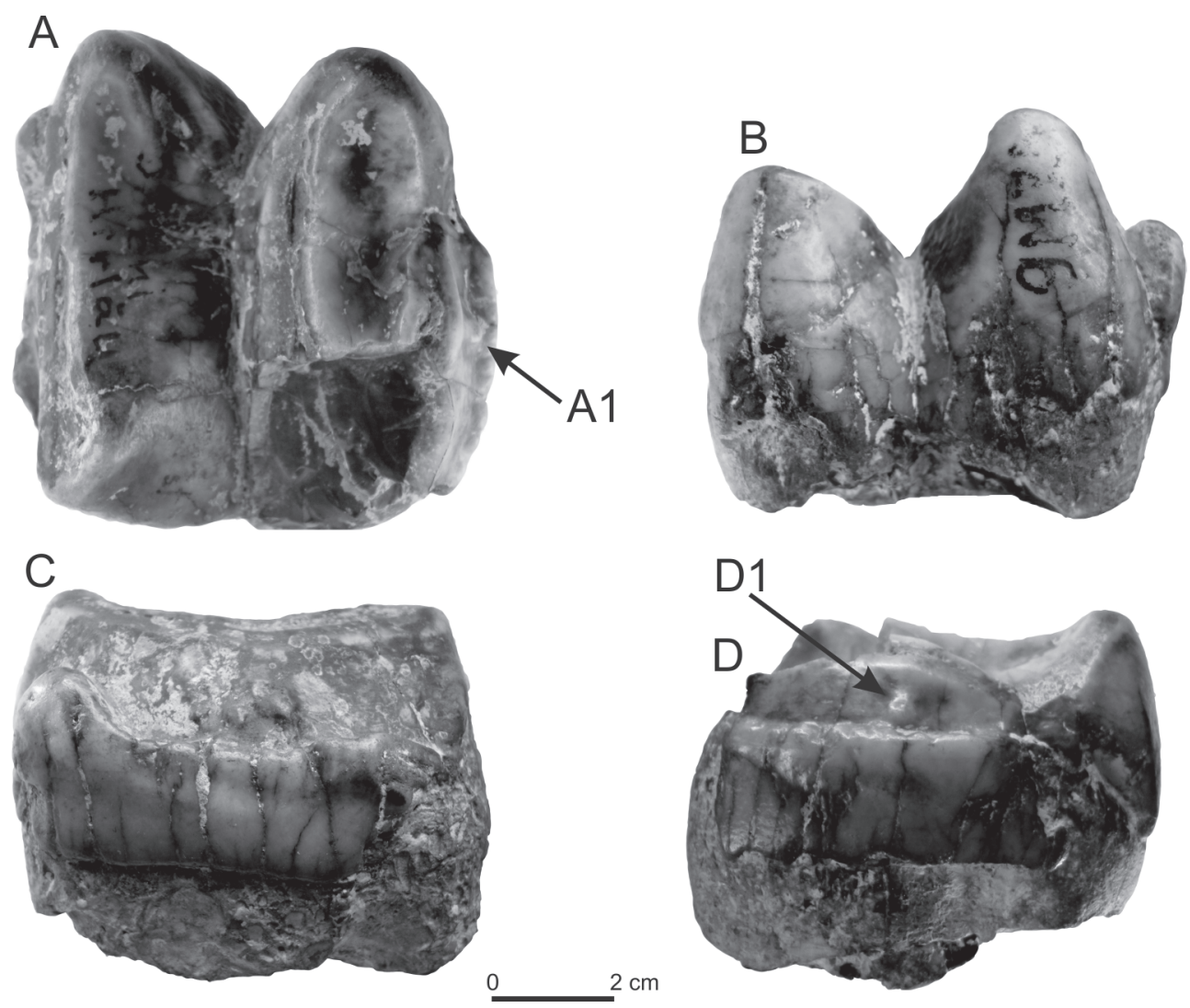

Fig. 9. M2 of Deinotherium giganteum from the Pietrăria Hill Quarry (Deleni, laşi County)

A - occlusal view; B - lingual view; C - mesial view; D - distal view; A1, D1 - tubercle over the distal cingulum

Several details on occlusal morphology can be added, especially on crista development (Fig. 9). The protoloph seems to be wider than the approximated metaloph. The paracone and metacone are well-preserved, showing the higher buccal cones than the lingual one. A very short praeprotocrista can be observed connecting into a strong cusplet of the anterior cingulum. Also, a weak praeparacrista runs near the lingual side to join the same cingulum into a small cusplet (Fig. 9A, C). Only a short praemetacrista is obvious.

All the cones extend into posterior cristae, which are rather well developed for this molar. The postparacrista is longer and slightly blunter than the postprotocrista (Fig. 9A). Especially the posthypocrista is strong and exceeds in length the mid-line of the tooth, having the tendency to join with the preserved weak prostmetacrista (Fig. 9A, D). Near the midline of the tooth, a round and small tubercle arises over the posterior cingulum (Fig. 9A, A1, D, D1).

The posterior cristae would be peculiar for this molar: the weak postprotocrista and especially the posthypocrista (the preserved fragment), which is strong and exceeds in length the mid-line of the tooth, having the tendency to join with the buccal prostmetacrista (Fig. 9A, C).
Both the mesial and distal cingulums are obviously developed. The enamel thickness varies between 4.30 and $5.65 \mathrm{~mm}$ (Table 4).

Comparison of M2. The molar has the same well-defined postmetaloph ornamentation as the better preserved M2 sin. figured by Kaup (1829: tab. II, fig. 1). The posthypocrista is also longer than the median line tending to join postmetacrista near the narrow distal cingulum. The differences reside in the stonger postprotocrista and weaker postparacrista on the molar figured by Kaup, the weak cusplets of lateral cingulum on the valley ends, and the relative continuous anterior cingulum without distinct cusplets as in the Romanian molar.

A common feature can be highlighted in comparison with the two isolated M2 illustrated by Tobien [1988: pl. 2, fig. 11 (MTN 2613), 12 (MTN 2619)], namely a kind of roughness over the posterior cingulum (Tobien, 1988: 150: "parfois...peuvent se renforcer en une cuspule d'émail"). This feature was assigned to " $D$. levius" by Gräf (1957), but Tobien (1988) observed its variable presence on the same individual (but on $\mathrm{m} 1 \mathrm{~s}$ ), namely the roughness on the right molar and its absence on the left one (FSL 210396: pl. 4, fig. 21). The obvious postmetaloph is also similarly developed. The main difference

Biometric values of the M2 sin. (all values in $\mathrm{mm}$ ) Deleni specimen of Deinotherium giganteum

\begin{tabular}{|c|c|c|c|c|c|c|}
\hline \multirow{2}{*}{ Specimen } & \multicolumn{2}{|c|}{ L } & \multicolumn{2}{c|}{ Width of loph (1-2) } & \multirow{2}{*}{ LI } & \multirow{2}{*}{ Et } \\
\cline { 2 - 5 } & Lingual & Buccal & W1 & W2 & & \\
\hline M2 sin. Deleni & 79.73 & 70.94 & 78.27 & 76.27 & 0.98 & $4.30-5.65$ \\
\hline
\end{tabular}




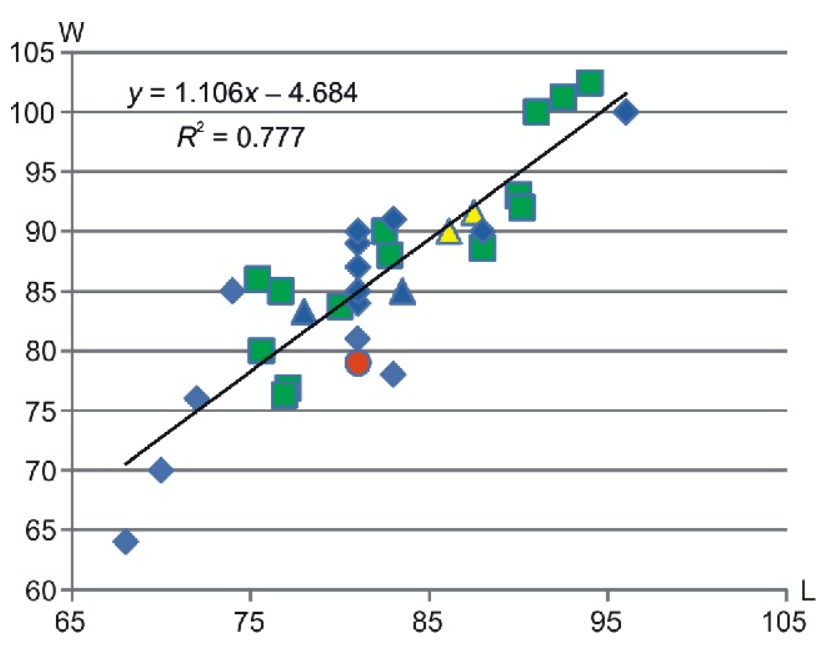

Fig. 10. Scatter diagrams of M2 (maximum length versus maximum width of lophs) for the compared deinothere specimens

The selected specimens are listed in Appendix 1; circle - Delen (laşi County); yellow triangle - Eppelsheim-Frohnstetten (Gräf, 1957), blue triangle - Sopron (Gasparik, 1993), square - Montredon (Tobien, 1988), rhombus - Wien - Wolkerdorf (Huttunen, 2002b)

is the shape of M2 from Montredon, which have unusually larger protolophs than the metalophs. The crista development is variable.

Huttunen (2002b) mentioned a rich M2 assemblage from Lower Austria and Burgenland (see Appendix 1), characterized by variable biometric data (various ratios between the length and maximum width of lophs, and by various ratios between the protoloph and metaloph widths). The crista pattern is similar to the M2 from Deleni; each cusplet extending into a variable crista. For the Romanian deinothere molar, the lingual ones are longer than the former specimens. The postmetaloph ornamentation is very variable or even absent for the Austrian deinothere molars without taxonomic consequence.

The metric analysis placed the isolated M2 of Deleni in the middle part of the variation range for $D$. giganteum (Fig. 10). The WL ratio $(\mathrm{Mw} / \mathrm{ML}=0.98168)$ fits in the mid-lower part of the dataset (Fig. 10), being comparable with the Wilfersdorf and Bruck a.d. Leitha specimens (Huttunen, 2002b).

\section{CONCLUSIONS}

Starting with a summary of medium-sized deinothere fossils of Romania, the paper describes and compares morphologically and metrically two remains of Deinotherium giganteum from the Miocene rocks of the Eastern Carpathians Foreland.
The first specimen is the right hemimandible fragment of Drăgeşti (Bacău County), with well-preserved $\mathrm{m} 1$ and $\mathrm{m} 2$, and only the roots of p3-p4 and m3. A proximal fragment of left tibia collected from the same outcrop was also added. The second specimen is an isolated M2 sin. found in the Pietrăria Hill Quarry (Deleni, laşi County).

The short fragment of the left hemimandible hinders appropriate comparison with the well-preseved specimens. The presence of barely noticeable oriffice under the $\mathrm{p} 4$ which would represent the medial mental foramen is a significant gain taking into account that it was observed only for the Subfamily Elephantinae so far.

The teeth show the conservative occlusal morphology which was emphasized by the previous researchers for the deinotheres. The intraspecific variation consists in the lophid widths, sculptural cristid pattern, valley and cingulid development, and accessory or cingular cusplets. The metric analysis placed the specimens within the variation range of the European specimens of $D$. giganteum. The tibia fragment is typical for the deinotheres: the shift of the articular facets, the massive tibial tuberosity occuring lower on the shaft, the slightly developed intercondylar eminence and lateral tubercles etc. Also, the oval articular facet of the fibula is conspicuously preserved on the plantar side. Instead, it is uncommon the shapes for the medial and lateral articular facets. The smaller dimensions in comparison with similar bones was explained by a different ontogentic stage:

The age of the fossil-bearing layers of both specimens (late Bessarabian MN 9 and Early Bessarabian ?MN 7-8-MN 9, respectively) was assessed determined by mollusk species following the integration in the regional lithostratigraphic concept and in well in accordance with the biostratigraphy based on mollusks.

The paper reinstates these specimens in the scientific literature enlarging the comparison dataset for this species and its spreading in Eastern Europe.

Acknowledgements. Many thanks go to Dr D.I. Maftei and S.C. Roşu for their help during the work and to Dr G. Gurău, the manager of the Museum of Natural Sciences "Ion Borcea" Bacău who allowed the access to the fossil specimen. I am also grateful to M. Aiglstorfer (State Museum of Natural History Stuttgart and Senckenberg Center for Human Evolution and Palaeoenvironment Tübingen), M. Böhme (University of Tübingen, Institute for Geoscience and Senckenberg Center for Human Evolution and Palaeoenvironment Tübingen), and M. Gasparik (Hungarian Natural Museum, Budapest) for their thorough reviews and fruitful comments which significantly improved the manuscript. Thanks are also due to Anonymous Reviewer for his useful observations and comments which definitively contributed to the final version of the paper.

\section{REFERENCES}

Aiglstorfer, M., Göhlich, U.B., Böhme, M., Gross, M., 2014. A partial skeleton of Deinotherium (Proboscidea, Mammalia) from the late Middle Miocene Gratkorn locality (Austria). Palaeobiodiversity and Palaeoenvironment, 94: 9-70.

Athanasiu, S., 1907. Contribuţiuni la studiul faunei terţiare de mamifere din România. Anuarul Institutului Geologic al României, 1: 129-214.
Bachmeyer, F., Zapfe, H., 1976. Ein bedeutender Fund von Dinotherium aus dem Pannon von Niederösterreich. Annalen des Naturhistorischen Museums in Wien, 80: 145-162.

Böhme, M., Aiglstorfer, M., Dieter U.D., Kullmer, O., 2012. The Antiquity of the Rhine River: stratigraphic coverage of the Dinotheriensande (Eppelsheim Formation) of the Mainz Basin 
(Germany). PLos ONE, 75: e36817, doi:10.13717/journal.pone.0036817

Codrea, V., 1989. New complements on Deinotherium giganteum KAUP from the Brusturi Pontian (Bihor District). Crisia, Muzeul Tării Crişurilor Oradea, 19: 773-783.

Codrea, V., 1994. A priority issue: Deinotherium proavum Eichwald or Deinotherium gigantissimum Stefănescu? In: The Miocene from the Transylvanian Basin-Romania (ed. E. Nicorici): 105-110. Special issues: Geological Formations of Transylvania, Romania. Babeş-Bolyai University, Cluj-Napoca.

Codrea, V., Andreica, D., 1988. Sur quelques restes de Proboscidiens fossiles de Transylvanie. Studia Universitatis Babeş-Bolyai, Geologie-Geografie, 33: 89-96.

Codrea, V., Ciobanu, R., 2008. Deinothere and mastodons from the Brukenthal Museum Natural Science Collection. North-Western Journal of Zoology, 4: 108-118.

Codrea, V., Margin, C., 2009. The environments of the Uppermost Miocene vertebrates from Derşida (Northwestern Rumania Sălaj County). Oltenia. Studii şi comunicări. Ştiinţele naturii, 25 385-390.

Codrea, V., Laslo-Faur, Al., Dudas, C., Hosu, Al., Barbu, O., 1991 The first Romanian record of Deinotherium levius Jourdan from the Sarmatian diatomic-tuffaceous complex at Minişu de Sus (Tauţ, Arad district). In: The Volcanic Tuffs from the Transylvanian Basin, Romania (ed. I. Mârza): 103-108. Special issues: Geological Formations of Transylvania, Romania. Babeş-Bolyai University, Cluj-Napoca.

Codrea, V., Rătoi, B.G., Ursachi, L., Fărcaş, C., 2016. A large deinothere (Mammalia: Proboscidea) in the Late Miocene of the Moldavian Platform at Huşi (Vaslui County). Oltenia. Studii şi comunicări. Ştiinţele Naturii. Muzeul Olteniei Craiova, 32 $20-28$.

Duranthon, F., Antoine, P.O., Laffont, D., Bilotte, M., 2007. Contemporanéité de Prodeinotherium et Deinotherium (Mammalia, Proboscidea) à Castelnau-Magnoac (Hautes-Pyrénées, France). Revue de Paléobiologie, 26: 403-411.

Éhik, J., 1930. Prodinotherium hungaricum nov. gen., nov. sp. Geologica Hungarica, Series Paleontologica, 6: 1-18.

Ferretti, M., Debruyne, R., 2011. Anatomy and phylogenetic value of the mandibular and coronoid canals and their associated foramina in proboscideans (Mammalia). Zoological Journal of the Linnean Society, 161: 391-413.

Gasparik, M., 1993. Deinotheres (Proboscidea, Mammalia) of Hungary. Annales Historico-Naturales Musei Nationalis Hungarici, 85: 3-17.

Gasparik, M., 2001. Neogene proboscidean remains from Hungary; an overview. Fragmenta Palaeontologica Hungarica, 19: 61-77.

Gaudry, A., 1862-1867. Animaux fossiles et géologie de l'Attique. F. Savy Editeur, Paris.

Geraads, D., Kaya, T., Mayda, S., 2005. Late Miocene large mammals from Yulafli, Thrace region, Turkey, and their biogeographic implications. Acta Palaeontologica Polonica, 50 523-544.

Ginsburg, L., Chevrier, F., 2001. Les Dinothères du bassin de la Loire et l'évolution du genre Deinotherium en France. Symbioses, 5: 9-24.

Göhlich, U.B., 1999. Order Proboscidea. In: The Miocene Land Mammals of Europe (eds. G. Rössner and K. Heissig): 157-168. Pfeil, Munich.

Gräf, I., 1957. Die Prinzipien des Artbestimmung bei Dinotherium. Paläontographica, 108: 131-185

Harris, J.M., 1973. Prodeinotherium from Gebel Zelten. Bulletin of the British Museum (Natural History), Geology, 23: 283-348.

Harris, J.M., 1975. Evolution of feeding mechanisms in the family Deinotheriidae (Mammalia; Proboscidea). Zoological Journal of the Linnean Society, 56: 331-362.

Harris, J.M., 1979. Deinotherioidea and Barytherioidea. In: Evolution of African Mammals (eds. V.J. Maglio and H.B.S. Cooke) 315-332. Harvard University Press.

Haynes, G., 1991. Mammoths, Mastodonts, and Elephants: Biology Behavior and the Fossil Record. Cambridge University Press.
Hilgen, F.J., Lourens, L.J., Van Dam, J.A. with contributions by Beu, A.G., Boyes, R.A., Cooper, R.A., Krijgsman, W., Ogg J.G., Piller, W.E., Wilson, D.S., 2012. The Neogene Period. In: The Geological Time Scale (eds. F.M. Gradstein, J.G. Ogg, M. Schmitz and G. Ogg): 923-978.

Huttunen, K., 2002a. Systematics and taxonomy of the European Deinotheriidae (Proboscidea, Mammalia). Annalen des Naturhistorischen Museums in Wien, 103: 237-250.

Huttunen, K., 2002b. Deinotheriidae (Proboscidea, Mammalia) dental remains from the Miocene of Lower Austria and Burgenland. Annalen des Naturhistorischen Museums in Wien, 103: $251-285$

Huttunen, K., Göhlich, U.B., 2002. A partial skeleton of Prodeinotherium bavaricum (Proboscidea, Mammalia) from the Middle Miocene of Unterzolling (Upper Freshwater Molasse, Germany). Geobios, 35: 489-514.

Ionesi, L., 1994. Geologia unităţilor de platformă şia Orogenului Nord-Dobrogean. Editura Tehnică, Bucureşti.

Ionesi, L., Ionesi, B., Roşca, V., Lungu, Al., Ionesi, V., 2005. Sarmaţianul mediu şi superior de pe Platforma Moldovenească. Editura Academiei Române.

Ionesi, V., 2006. Sarmaţianul dintre Vales Siretului şi Valea Şomuzului Mare. Editura Universităţii "Alexandru Ioan Cuza" laş.

Jeanrenaud, P., 1967. Geologia regiunii văii superioare a rîului Bîrlad. Analele Ştiinţifice ale Universităţii "Alexandru Ioan Cuza" din laşl, secţ. II b, Geologie-Geografie, 13: 29-37.

Jeanrenaud, P., 1971. Harta geologică a Moldovei centrale dintre Siret şi Prut. Analele Ştiinţifice ale Universităţii "Alexandru Ioan Cuza”" laşi, Secţ. II b, Geologie-Geografie, XVII: 65-78.

Jurcsák, T., 1973. Deinotherium giganteum Kaup din zăcămintele de bitum de la Derna. Nymphaea. Foliae naturae Bihariae, 1: 301-311.

Jurcsák, T., 1982-1983. Răspîndirea proboscidienilor în nord-vestul României. Nymphaea. Foliae naturae Bihariae, 10: 65-85.

Kappelman, J., Rasmussen, D.T., Sanders, W.J., Feseha, M., Bown, T., Copeland, P., Crabaugh, J., Fleagle, J., Glantz, M., Gordon, A., Jacobs, B., Maga, M., Muldoon, K., Pan, A., Pyne, L., Richmond, B., Ryan, T., Seiffert, E.R., Sen, S., Todd, L., Wiemann, M.C., Winkler, A., 2003. Oligocene mammals from Ethiopia and faunal exchange between Afro-Arabia and Eurasia. Nature, 426: 549-552.

Kaup, J.J., 1829. Neues Säugthier, Deinotherium: Deinotherium giganteum. Isis, 22: 401-404.

Kaup, J.J., 1832. Déscription d'ossements fossils de mammifères inconnus jusqu'à présent, qui se trouvent au Musèum grandducal de Darmstadt avec figures lithographiées. J.G. Heyer, cinquième cahier: 91-119.

Kovachev, D., Nikolov, I., 2006. Deinotherium thraceiensis sp. nov. from the Miocene near Ezerovo, Plovdiv District. Geologica Balcanica, 35: 5-40.

Lambert, W.D., Shoshani, J., 1998. Proboscidea. In: Evolution of Tertiary Mammals of North America (eds. C.M. Janis, K.M. Scott and I.I Jacobs): 606-621. Cambridge University Press.

Macarovici, N., Zaharia, N., 1968. Asupra unor mamifere fosile din Sarmaţianul Podişului Moldovenesc. Buletinul Societăţii de Ştiinţe Geologice din R.S. România, X: 217-227.

Moroşan, N., 1936. Dinothérides de Béssarabie. Contribution à l'étude de la dentition et de la distribution paléogéographique des Dinotheridés de Roumanie. Annales Scientifiques de I'Université de Jassy, 22: 256-279.

Mottl, M., 1969. Bedeutende Proboscidier-neufunde aus dem Altpliozän (Pannonien) Südost-Österreichs. Österreichische Akademie der Wissenschaften, Mathematisch-Naturwissenschaftliche Klasse, Denkschriften, 115.

Mottl, M., 1970. Die Säugetierfunde von St. Oswald bei Gratwein westlich von Graz in der Steiermark. Festschrift des Landesmuseums Joanneum Graz: 299-320.

Paraschiv, D., 1979. Platforma Moesică şi zăcămintele ei de hidrocarburi. Editura Academiei RSR, Bucureşti. 
Pickford, M., Pourabrishami, Z., 2013. Deciphering Dinotheriensande deinotheriid diversity. Palaeobiodiversity and Palaeoenvironments, 93: 121-150.

Răileanu, V., Tătaru, D., Grecu, B., Bala, A., 2012. Crustal models in Romania - II. Moldavian Platform and adjacent areas. Romanian Journal of Physics, 57: 1438-1454.

Roth, V.L., 1984. How elephants grow: heterochrony and the calibration of developmental stages in some living and fossil species. Journal of Vertebrate Paleontology, 4: 126-145.

Roth, V.L., 1992. Quantitative variation in elephant dentitions: implications for the delimitation of fossil species. Paleobiology, 18: 184-202.

Sanders, W.J., Kappelman, J., Rasmussen, D.T. 2004. New large-bodied mammals from the late Oligocene site of Chilga, Ethiopia. Acta Palaeontologica Polonica, 49: 365-392.

Săndulescu, M., 1984. Geotectonica României. Editura Tehnică Bucureşti.

Săndulescu, M., Visarion, M., 1988. La structure des plateformes situées dans l'avant-pays et au-dessous des nappes du flysch des Carpates Orientales. Studii Tehnice şi Economice, seria D. Geofizică, 15: 62-67.

Shoshani, J., Tassy, P., 2005. Advances in proboscidean taxonomy and classification, anatomy and physiology, and ecology and behavior. Quaternary International, 126: 5-20.

Smith, K.M., Fisher, C.D., 2013. Sexual dimorphism and inter-generic variation in proboscidean tusks: multivariate assessment of American Mastodons (Mammut americanum) and extant African elephants. Journal of Mammalian Evolution, 20: 279-360.

Şova, C., 1963. Prezenţa lui Dinotherium giganteum Kaup pe cursul mijlociu al Siretului. Societatea de Ştiinţe Naturale şi Geografie din Republica Populară Română. Editura Academiei Române, II: 223-226.

Ştefan, P., 1989. Geologia regiunii Dealului Mare-Hîrlău şi perspectivele în resurse minerale utile. Ph.D. thesis, University of Alexandru Ioan Cuza laşi.

Ştefănescu, G., 1879. Descoperirea unei măsele de Deinotheriu în România. Analele Societăţii Academice Române, 1: 101-104.

Ştefănescu, G., 1891. On the existence of Deinotherium in Roumania. GSA Buletin, 3: 81-83.
Ştefănescu, Gr., 1895. Dinotherium gigantissimum ŞTEF. Anuarulu Museului de Geologia şi de Paleontologia Bucuresci, 1 (1894): 126-199.

Ştefănescu, Gr., 1899. Dinotherium gigantissimum Ştef. Le squelette de Mânzaţi. Anuarulu Museului de Geologia şi de Paleontologia, Bucuresci, 3 (1896): 110-145.

Ştefănescu, Gr., 1905. Rămăşiţe de Deinotherium în România găsite încă de pe la începutul secolului trecut. Analele Academiei Român. Memoriile Secţiunii Ştiinţifice. Bucureşti, 2 (1904-1905): 1-7.

Ştefănescu, Gr., 1910. Dinotherium gigantissimum din Miocenul superior. Anuarulu Museului de Geologia şi de Paleontologia, Bucureşti, 4 (1897): 6-43.

Tassy, P., 1996a. Dental homologies and nomenclature in the Proboscidea. In: The Proboscidea. Evolution and Palaeoecology of Elephants and Their Relatives (eds. J. Shoshani and P. Tassy): 21-25. Oxford University Press, Oxford/New York/Tokyo.

Tassy, P., 1996b. Growth and sexual dimorphism among Miocene elephantoids: the example of Gomphotherium angustidens. In: The Proboscidea. Evolution and Palaeoecology of Elephants and Their Relatives (eds. J. Shoshani and P. Tassy): 92-100. Oxford University Press, Oxford/New York/Tokyo.

Tărăpoancă, M., 2004. Architecture, 3D geometry and tectonic evolution of the Carpathians foreland basin. Ph.D. thesis, Vrije Universiteit, Faculty of Earth and Life Sciences, Amsterdam.

Tobien, H., 1988. Contributions a l'étude du gisement miocène supérieur de Montredon (Herault). Les grands Mammifères. 7 Les proboscidiens Deinotheriidae. Palaeovertebrata, Mémoire Extraordinaire 1988: 135-175.

Vergiev, S., Markov, G.N., 2010. A mandible of Deinotherium (Mammalia: Proboscidea) from Aksakovo near Varna, Northeast Bulgaria. Palaeodiversity, 3: 241-247.

Visarion, M., Săndulescu, M., Stănică, D., Velciu, Ş., 1988. Contributions à la connaissance de la structure profonde de la plateforme Moesienne en Roumanie. Studii Tehnice şi economice, D, Geofizică, 15: 211-222.

Visarion, M., Săndulescu, M., Roşca, V., Stănică, D., Atanasiu, L., 1990. La Dobrogea dans le cadre de l'avant-pays carpatique. Revue Roumaine de Géophysique, 34: 55-65. 